\title{
CAPACITY BUILDING IN FOOD COMPOSITION FOR AFRICA
}

\author{
Hettie C Schönfeldt ${ }^{* 1,2}$ \& Nicolette Hall ${ }^{1,2}$ \\ ${ }^{1}$ Institute of Food, Nutrition and Wellbeing, University of Pretoria, Pretoria, South Africa \\ ${ }^{2}$ Department of Animal and Wildlife Sciences, University of Pretoria, Pretoria, South Africa \\ *Corresponding author: hettie.schonfeldt@up.ac.za, Fax: +27 123612333
}

\section{ABSTRACT}

Capacity building in food and nutrition involves more than formal training and individual development. Such a process is long term and continues, requiring lasting mentorship, coaching and leadership development, including individual commitment to continued self-development. It expands to include the development of knowledge and skills of an individual within his/her organizational or institutional arrangements, and requires buy-in and support from his/her institution or organization, as well as other funding bodies involved in agriculture and health. It needs to be supported by government and be part of the regional and international agenda for agriculture and health.

Towards this aim, the International Network of Food Data Systems (INFOODS), as a joint $\mathrm{FAO} / \mathrm{UNU}$ project, was formed and represents an international technical cooperation of networks on food composition with an objective to coordinate, encourage and facilitate activities in order to generate national and regional food composition data which would be of high quality, adequate quantity and accessible to users. Under the auspices of INFOODS, an African Network of Food Data Systems (AFROFOODS) was established in September 1994, and a number of training courses, educational and scientific publications, posters, presentations and 
visits were hosted, organized and delivered with the aim to build enthusiasm, long term commitment and capacity in food composition within the AFROFOODS region. Formal training and human resource development were the major focus to take food composition forward in Africa. Significant progress has been made in food composition activities, but constraints including lack of organizational and institutional commitment and financial support are straining the pace of progress. The focus on nutrition is currently high on the international agenda in order to be able to report on the Millennium Development Goals (MDGs) in 2014. This offers a unique opportunity to educate governments on the link between agriculture and nutrition and in particular the contribution of the nutrient composition of foods with a specific focus on biodiversity of local foods and sustainable diets on health.

Key words: Food composition, Africa, AFROFOODS, INFOODS, Capacity building, leadership, nutrition, nutrient content, health, agriculture, sustainable diets 


\section{HIGHLIGHTS}

- Food composition plays an integral part in the progress towards achieving food security through forming the scientific base on understanding the inherent nutrient quality of foods, particularly local foods

- During the follow up meeting of AFROFOODS in 2000 it was re-divided into sub-regions according to proximity and language, and working groups as well as a plan of action were established. Since this meeting numerous of training courses, educational and scientific publications, posters, presentations and visits were delivered with the aim to build capacity in food composition within Africa.

- Food composition activities in Africa and the importance thereof should be highlighted in programmes and in organizations with mandates to alleviate malnutrition in Africa.

- Future priorities should include increased investment by governments and institutions in supporting both infrastructure (i.e. analytical instruments) and the development of human resources, including training.

\section{THE IMPORTANCE OF FOOD COMPOSITION FOR AFRICA}

Millennium Development Goal One set the target to 'halve, between 1990 and 2015, the proportion of people who suffer from hunger' (United Nations, 2010). Currently, 820 million people are affected by hunger in developing countries, and particularly in Africa, these numbers are increasing, moving further away from this goal. Improving food security is important for global reduction of hunger and poverty, and for economic development (Postnote, 2006). Food security and insecurity are terms used to describe whether or not people have access to sufficient quantities and 
quality of foods. Food security exists when all people, at all times, have physical, social and economic access to sufficient, safe and nutritious food which meets their dietary needs and food preferences for an active and healthy life (FAO, 2003).

Albert Einstein (1879-1955) said: "We can't solve problems by using the same kind of thinking we used when we created them".

To increase knowledge on food quality in the aim to combat food insecurity, data on the composition of the foods are required. This need has not been significantly prioritized in most developing countries, and is overshadowed by many other areas including public health nutrition and agricultural economics. Food quality inherently includes the nutritional quality of the food, i.e. the type and amount of nutrients present in the food source (nutritional composition). The International Network of Food Data Systems INFOODS is a joint Food and Agricultural Organizations (FAO) and United Nations University (UNU) project, launched in the late 1980's to promote international cooperation in the acquisition and interchange of quality data on the composition of foods, in forms appropriate to meet the needs of government agencies, nutrition scientists, health and agriculture professionals, policy makers and planners, food producers, processors and retailers, and consumers (FAO, 2011). Expected outcomes of network activities include to maintain closer inter-country linkages, and increase interaction between member countries, and to establish and further develop international linkages with other regional centres. Furthermore it aims to develop regional databases which will help fulfil the data needs of member countries, in particular of those where food composition data are lacking or not completely accessible (FAO, 2011). 
Under the auspices of FAO, the World Health Organization (WHO), UNU and the University of Ghana, an organizational meeting of AFROFOODS (the African regional food composition database network) was held in September 1994 in Ghana. This meeting was held to instate national networks for promoting, coordinating and improving food composition work and creating national food composition databases. To stimulate the production of new food composition data, the FAO and UNU joined efforts through activities such as providing much needed fellowships for training participants in the different regions. During a follow-up meeting of AFROFOODS in Dakar (June 2000) sub-regions were re-divided based on language, food culture, availability and distribution (Table 1). These sub-regions include the Eastern, Central and Southern African Food Composition Data System (ECSAFOODS), the Western African Food Composition Data System (WAFOODS), Central African Food Composition Data System (CAFOODS), and the Northern African Food Composition Data System (NAFOODS). A plan of action at national, sub-regional and international level was established, and various working groups were appointed (Tables 2 and 3).

In the past, FAO has contributed to a series of historical food composition tables between the 1950's and the 1980's, including the Food composition tables for international use (1949), Food composition table for use in Africa (1968), Food composition table for use in East Asia (1972), Table de composition des aliments \& l'usage (1976) and Food composition tables for the near east (1982). A more recent accomplishment for food composition in Africa, was the publication entitled Food Composition of selected foods from West Africa (Stadlmayer et al., 2010) containing nearly 200 foods, and its update West African Food Composition Table (Stadlmayr et al., 2012) containing 472 foods and 28 components. The various other food 
composition tables currently available for African countries are listed in Table 4. Many of these are only available at a single institution in out-dated, faded, paperback formats, and most contain limited traditional foods or own data, as most data values are borrowed from developed country-databases, e.g. the USDA Food Composition Database.

\section{CAPACITY BUILDING IN FOOD COMPOSITION FOR AFRICA}

\subsection{Plan of Action for food composition in Africa}

As part of the International Conference on Nutrition (ICN) follow-up programme, at the AFROFOODS meeting held in Dakar in June 2000, a Plan of Action for food composition was formulated. This action plan involved activities at national, subregional, and international levels (Table 2). National (country) activities in the action plan included the establishment of national networks, coordination, generation and compilation of national data, and validation of existing data, as well as communication, training and human resource development. Sub-regional activities mainly focussed on establishing and facilitating steering committees and working groups within each sub-region. Activities at international level (AFROFOODS) mainly related to the encouragement of national and sub-regional members to publish research findings and to support them to attend knowledge exchange opportunities such as conferences.

During an AFROFOODS meeting, held in Pretoria, South Africa on 6 June 2001, six international working groups were established and members volunteered and were elected from the various sub-regional data centres. These working groups included training, analytical procedures, communication and dissemination, the use of food composition databases, food legislation, standards and regulations, and a working 
group on data compilation (Table 3). These working groups were established to enable knowledge-sharing networks between sub-regions and countries, yet outputs encouraged by these international working groups are at most very limited. In addition to these international working groups, one of the Action Plan activities (Table 2) was to establish working groups within each of the sub-regions within AFROFOODS. No formal progress on these networks can be reported.

\subsection{Capacity building during the past two decades}

Since the inauguration of AFROFOODS in 1994 where capacity building was identified as the major priority, seven training courses were presented in Africa funded by FAO, UNU, Wageningen University VLAG, Agricultural Research Council (ARC) and University of Pretoria (UP). These training courses included four ECSAFOODS courses, two WAFOODS and CAFOODS courses, and most recently an International course. These seven courses enabled 134 individual participants from 24 different African countries to participate. In addition, numerous food composition courses were presented by other International organizations since 1992, at which another 41 African individuals participated (Table 5). A list of all past participants is available on the INFOODS website (www.fao.org/infoods). Many of the participants never became, or are no longer, active in food composition as they changed focus to further their own careers as career paths in food composition within most African countries remain limited.

Face-to-face training is costly and since many countries identified 'access to software' a constraint to progress, FAO developed an electronic training module on food composition in 2011. This training module is available on the FAO INFOODS website. Furthermore various downloadable software programmes including 
compilations tools are currently available to download, also at no cost (www.fao.org/infoods). No formal knowledge on the application of these tools is currently known, yet constraints such as lack of access to high speed continuous internet and computers in many underdeveloped African countries could limit the knowledge and ability of volunteering individuals to utilise these resources. Institutional support will be essential to provide infrastructure and resources to enable the utilisation of these tools to further food composition within countries. The freely available software tools are a tremendous step forward for food composition developments globally, but they need to be widely advocated to inform potential interested parties, and enable institutional buy-in to provide infrastructure and career building platforms for food composition activities. FAO could play a significant role as knowledge broken in this regard.

Although increased knowledge for individuals through training remains an essential part of capacity building, capacity development in food and nutrition involves more than formal training, but includes human resource development, as well as organizational and institutional development (Gurinovic et al., 2010). Towards assessing this, the quality and quantity of research publications are often used as benchmarks to monitor the performance of innovation (Jeenah \& Pouris, 2008). According to the Web of Science Database, there are nearly 1500 scientific journal articles related to food composition published by authors from African countries to date. Of these, nearly 1300 were published since AFROFOODS commenced in 1994. Since the re-alignment of AFROFOODS priorities in 2000 , the publication of scientific articles related to food composition from Africa escalated, with nearly 1000 scientific articles on food composition published since 2001. Refer to Table 6 for the list of keywords used to conduct the search. 
Globally, from the period 2001 to 2010 , more than 20,000 ISI accredited journal articles were published in the subject category of food composition and quality, of these more than $20 \%$ were specifically related to developing countries. Just more than $1,000( \pm 5 \%)$ of the total number of contribution in the field were contributions made by African researchers (either as author or co-author) (CAB Direct, 2011; Thompson Reuters, 2011). Publications from Egypt, Nigeria and South Africa contributed to more than one third of the total number of recognised articles from Africa in this time, indicating a generally low level of contribution from the other African countries, despite training.

Since the establishment of AFROFOODS, four country tables have been published, and particularly since capacity building has been introduced this has doubled to include updates of existing tables, including six new country tables and one regional table. Many countries have also indicated that they are busy compiling or continuing to update existing tables. Apart from the role of AFROFOODS, this increase can also be due to the focus on food labelling within Codex for food trade (changes within the policy environment) which is placing food composition into country agendas.

Towards knowledge exchange, the sixth International Food Database Conference $\left(6^{\text {th }}\right.$ IFDC) was held in Pretoria, South Africa in September 2005. Approximately 100 participants attended the conference, and nearly half of these delegates were from African countries. 19 oral papers, and 16 posters, were presented by authors from seven different African countries. Three of the 13 peer reviewed articles in the proceedings published in the Journal of Food Composition and Analysis (20(8), 655740), where from Africa. 


\subsection{A case study on South Africa}

Although South Africa is the third leading country in terms of scientific publications in the field of food composition and quality, but the publications from South Africa have been, on average, cited the most by other authors (higher citation index) (Jeenah \& Pouris, 2008; Thompson Reuters, 2011). The South African national food composition database, under the auspices of the Medical Research Council (MRC), South African Food Data System (SAFOODS) has seen an increase in the volume of nutrient composition values for own South African foods. Within the 1991 edition of the MRC National Food Composition Tables only $18 \%$ of the foods had original South African values, and more than three quarters of the values were borrowed from other databases such as the United States Department of Agricultural Food Composition Databank. In the newest edition of the MRC Condensed Food Composition Tables for South Africa (Wolmerans et al., 2010), nearly 50\% of the data entries are own South African values.

Among others, various nutrient composition studies have been performed on South African animal products since the late 1990's, including the nutrient content of South African lamb and mutton, beef and milk and milk products (Schönfeldt et al., 1997; Schönfeldt et al., 1998; Smit \& Schönfeldt, 2006a; Smit \& Schönfeldt, 2006b; Van Heerden \& Schönfeldt, 2007). These composition studies formed part of formal training at the University of Pretoria (UP) and were done as part of the requirements for 12 post graduate students, of which four were doctoral degrees. The research was done in partnership with the Agricultural Research Council (ARC), and funded through the relevant industry partners. To control the quality of the data, sampling protocols were developed by consensus, and were market related thus including 
variables such as production region, breed, feedings regimes etc. Chemical analyses were performed in duplicate at SANAS accredited laboratories by means of accredited methodologies. The research has been published in peer-reviewed journals and presented at national and international conferences. Possible reasons for the success of South African in terms of capacity building includes not only the training of individuals through training courses presented through the AFROFOODS network, and establishment of national networks (SAFOODS), but due to a favourable policy environment and monetary support from the various research institutions which created career opportunities within food composition, including data generation (UP \& ARC), compilation (UP \& MRC) and coordination of national data (MRC). In turn, these career opportunities and support from institutions provided individuals with the capacity to advocate the importance of composition data to governmental departments, single commodity industries, etc., and submit applications for funding for product analysis, compilation, and coordination.

\section{THE FUTURE OF FOOD COMPOSITION IN AFRICA}

Food composition activities in a structured and collective manner at country and regional level are still only occurring in a handful of countries, similar to agricultural research and development. This is mainly due to lack of national, organizational and institutional prioritization, neglected infrastructure, and underinvestment (IFPRI, 2011). Recent global events such as the food price crises, global recession and climate change had a profound effect on global hunger, health and agriculture. Many countries within Africa, particularly those from West Africa suffering from extreme fragile funding systems, face critical capacity and investment challenges, and in 
many African countries, national investment has practically diminished, leaving these countries dependent on unpredictable, external funding sources (IFPRI, 2011).

In 2009, the United States President Barack Obama signed a Presidential Memorandum on Scientific Integrity, with the aim to restore scientific integrity in government decision making (Whitehouse, 2009). Keeping this in mind, public policy to decrease hunger and food insecurity should be guided by accurate and objective scientific information. Within the food composition family, it is well recognised that nutrient content of foods form a scientific basis for public health nutrition. As often quoted, the knowledge of the chemical composition of foods is the first essential in dietary treatment of disease or in any quantitative study of human nutrition (McCance and Widdowson, 1940). Unfortunately, the acknowledgment of the role of food composition in human nutrition is still limited in many other subject areas including public health nutrition, agricultural economics and policy formulation to alleviate hunger and food insecurity. FAO's specific role involves at present interalia the provision of advice and comments to the Codex Alimentarius Commission during the development of international standards for food trade (e.g. labelling), methods of analysis and sampling. The FAO INFOODS network could play a stronger knowledge broker role for food composition as part of their mandate to inform and advocate at international and regional level the contribution of food composition data to understanding nutrient intake and meeting nutrient requirements. Partnering with current programmes targeting vulnerable groups such infants (i.e. Scaling up Nutrition (SUN) 1000 days), pregnant and lactating women and the elderly.

There is a dire need to promote the importance of nutrient composition data as it relates to food varieties and evaluation of food intake data for nutrient requirements. 
Furthermore, international attention on the bioavailability of nutrients from different food sources, biodiversity in terms of nutrient content at cultivar and species level, and the relationship between the consumption of certain nutrients and disease development, has recently been highlighted. Unfortunately, in Africa, it seems that although these topics validate the importance of country-specific food composition data in combating food insecurity, it remains overshadowed by other priorities such as increasing sustainable agricultural productivity, trade and market stability and development, issues of gender and HIVIAIDS, safe drinking water, biotechnology, social transformation and ending the conflicts in Africa (Sustainable Developments, 2004). Furthermore challenges, including environmental, economic, technological, socio-cultural and political challenges, are likely to present additional competition for food composition activities to become prominent on the African agenda (Sunray, 2011).

During the 8th International Food Data Conference, held in Bangkok, Thailand, October 2009, a Bangkok Declaration was formulated stated that "in recognising the importance of food composition data to nearly all activities in nutrition and food quality and safety, as well as the continuing need for quality food composition data for public health, for agriculture, for the environment and for food trade, the delegates agreed to promote the science of food composition in multiple and diverse forums, including national, regional and international conferences, to undertake advocacy in the context of policy and programme development, to insure the integration of food composition principles in relevant activities, and to support in various ways the continuing development, maintenance and updating of food composition databases within sustainable infrastructures.” 
In line with this, at an AFROFOODS meeting in Dakar, Senegal, on Human Rights Day (9 Dec 2009), a call for action from the door of return for food renaissance in Africa was made (EISMV/FAO/UNU, 2009). During this call the degradation of ecosystems and the loss of food biodiversity were noted as causative to the increases in poverty and malnutrition in Africa. The call recognized that in order to conserve sustainable use of agriculture for food and nutrition, production systems would need to return to local crops and traditional food systems, and those traditional foods should form the basis of African diets. They called upon the sectors of public health, agriculture, environment and food trade to help reinforce and assist with food composition data on local foods, and stressed that food composition data be emphasized as the fundamental information underpinning almost all activities in human nutrition. The call ended with a request that the contribution of food composition be accredited internationally as one of the most important components for action in nutrition and food quality, food safety and nutrition security (EISMV/FAO/UNU, 2009).

Food and nutrition security in Africa is a multi-facetted industry extending well beyond the interests of government alone. With the deadline for progress on the MDG's approaching in 2014, food and nutrition security has been acknowledged as a matter of urgency globally. Apart from national governments and industries, specific international stakeholders with mandates towards aiding African nutrition and agriculture need to be targeted and informed on the role of food composition within these towards combating malnutrition. This is a collective responsibility of all involved or interested in food composition. Such visible organizations and professional bodies include the United Nations agencies (FAO, World Health Organization (WHO) etc.), the International Food Policy Research Institute (IFPRI), 
the African Development Bank, Bioversity International, Sustainable Nutrition Research for Africa in the years to come (SUNRAY), FoodAfrica, the African Nutrition Society, United States Agency for International Development (USAID), and the Comprehensive African Agriculture Development Program (CAADP), amongst others. Such organizations could play a significant role in improving awareness on the role of food composition data in human nutrition, and provide valuable financial and leadership support towards these functions - once again focussing the knowledge broker role that FAO INFOODS needs to play.

\section{CONCLUSIONS}

Food composition data plays an integral role in ensuring the success of programmes aimed at combating malnutrition in Africa. Yet Africa, with its low income economies, language barriers, differences in food culture and indigenous foods, along with regional priorities related to food and nutrition security, distinguishes the role of AFROFOODS from the role of the other INFOODS data centres. Africa is the world's second-largest and second-most-populous continent, yet it remains the world's poorest, undernourished and underdeveloped continent (World Population Prospects, 2011).

Collaboration between countries within Africa as part of AFROFOODS has provided some opportunities for capacity development in food composition data generation, compilation and use. However, Africa still falls behind other regions in progress towards achieving good quality country specific and regional food composition databases. Networks, such as AFROFOODS, can be useful tools for capacity building, mentoring and addressing the needs in food composition, but requires a 
prominent action plan, adequate resources, support funding and collaboration from national and international organizations, institutions and governments.

AFROFOODS, as a volunteer network, does not have the finances or ability to provide career opportunities or monetary support to individuals to enable full-time contribution to improving food composition in Africa. Furthermore, AFROFOODS has limited weight to contribute to policy development protocols in the various international, regional and country specific intervention programmes for food and nutrition security established by governments and other institutions. In the past, AFROFOODS focused on capacity building through targeted individual training, yet measuring sustainability has been limited. AFROFOODS should continue to play a networking role to coordinate the progress of activities by the sub-regions and most importantly, communicate through INFOODS to UN agencies to advocate the criticality of food composition in intervention programmes for food and nutrition security in Africa, as was done through the 2009 Call for Action.

Sub-regional data centres (ECSAFOODS, CAFOODS, WAFOODS and NAFOODS) could play a more prominent role in advocating career opportunities within country/regional industries, governments and other organizations to increase institutional capacity, including infrastructure and career opportunities. Furthermore, formal regional working groups, e.g. training working group, analytical procedures, use of food composition data, food legislation and standards, and a working group on data compilation, would need to be established. These working groups could perform the functions as stipulated in Table 3 within their regions and so increase capacity for food composition activities at sub-regional level. Without funding 
however, these activities remain on a voluntary basis, and the individual capacity and motivation for such activities in developing countries remain scarce.

\section{RECOMMENDATIONS}

In essence, capacity building through leadership and infrastructure development remains key priorities for the immediate future to equip people to lead, train and mentor others while assisting their own countries/regions to compile good quality food composition tables which reflect the individual food components including local food and preparation thereof in the diet of the unique people from the diverse landscapes of Africa.

A leadership program in food composition is proposed, focusing on development skills and personal empowerment. Such a program can be similar to the African Nutrition Leadership Programme (ANLP) with the purpose to assist in the development of future leaders in the field of human nutrition in Africa. Further examples includes the Agricultural Leadership Development Programme (ALDP) of the Department of Agricultural Economics, Extension and Rural Development (UP) and AgriSETA, and the Agribusiness Leadership and Mentorship Development at Stellenbosch University, which both aim to provide and develop management skills as well as analytical and creative decision-making competencies for managers and individuals who function at a strategic management level. At individual level, these candidates could establish networks and personal contact with policy makers to jointly establish nutrition agendas including food composition, and furthermore advocating the implications to policy makers on the nutrient quality of foods as part of agricultural as well as health and nutrition programmes, specifically focussing on 
the biodiversity of traditional, nutrient rich, foods in a sustainable diet for national or regional relevance.

FAO INFOODS, AFROFOODS and the regional data centres need to re-align strategies to further leadership development in food composition in Africa. Actions include the establishment of:

a) Supportive programmes, including training courses focussing on the specific needs and gaps for each region, falling within the scope and responsibility of the four regional data centres.

b) Supportive environments, including increased institutional capacity, career prospects and mentorship which need to be advocated through a strong top down (FAO,) and a bottom up (individual) approach.

c) Supportive policies to increase priority in nutrition and agricultural programmes to enable release of funds towards food composition activities.

Within all three these FAO INFOODS play a significant knowledge broker role to communicate the role of food composition towards achieving the Millennium Development Goals and progressing towards sustainable food and nutrition security for Africa. Furthermore, the success of AFROFOODS to increase food composition activities in Africa should be measured in future for effective evaluation. Some examples of indicators which could measure progress include, measuring the process, i.e. actions performed by regional data centres, measuring the outputs, i.e. food composition tables and scientific articles on food composition from African authors, and measuring advocacy outcomes, i.e. agricultural and health policies (including food composition activities towards sustainable food and nutrition security for Africa), or institutional capacity for food composition activities. 


\section{REFERENCES}

AFRICAN NUTRITION LEADERSHIP PROGRAMME (ANLP). 2012. $10^{\text {th }}$ Seminar, 13- 23 March 2012. South Africa. Available online at http://www.africanutritionleadership.org. Accessed 24 October 2011.

African Nutrition Society. (2011). Available online at http://www.answeb.org/. Accessed 19 October 2011.

Agricultural Leadership Development Programme (ALDP). (2012). Department of Agricultural

Economics, Extension and Rural Development and AgriSETA. Continuing Education, University of

Pretoria, Pretoria, South Africa. Available online at www.agriseta.co.za. Accessed 24 October 2011.

Bangkok Declaration. (2009). At the 8th International Food Data Conference, Bangkok, Thailand, 3rd October 2009. http://www.fao.org/infoods/index en.stm

Cab Direct. (2011). CABI's database platform. Accessed 18 October 2011. Available online at http://0www.cabdirect.org

EISMV/FAO/UNU. (2009). Report of the Sub-regional data centres coordinators meeting (AFROFOODS). 09-11 December 2009. Dakar - Senegal.

FAO. (2003). Trade Reforms and Food Security. Conceptualizing the linkages. Food and Agricultural Organization of the United Nations. Rome, 2003.

FAO. (2011). The International Network of Food Data Systems (INFOODS). Available online at http://www.fao.org/infoods. Accessed 24 October 2011.

FoodAfrica. (2011). Improving food systems in sub-Saharan Africa: responding to a changing environment. Available online at http://foodafrica.nri.org/index.html. Accessed 19 October 2011.

Gurinovic, M., Witthoft, C.M., Tepsic, J., Ranic, M., Hulshof, P.J.M., Hollman, P., Porubska, J., Gohar, A., Debeljak-Martacic, J., Petrovic-Oggiano, G., Novakovic, R., Glibetic, M. \& Oshaug, A. (2010). Capacity development in food composition database management and nutrition research and 
education in Central and Eastern European, Middle Eastern and North African countries. European Journal of Clinical Nutrition, 64(S3), s134-s138.

IFPRI. (2011). International Food Policy Research Institute. Sustainable Solutions for Ending Hunger and Poverty. Available online at www.ifpri.org. Accessed 19 October 2011.

Jeenaj, M. \& Pouris, A. (2008). South African research in the context of Africa and globally. South African Journal of Science, 104, $351-354$.

Lopes, C. \& Theisohn, T. (2003). Ownership, Leadership and Transformation. Can we do better capacity development? United Nations Development Programme. Earthscan Publications Ltd: London and Sterling, Virginia.

McCance, R.A. \& Widdowson, E.M. (1940). The chemical composition of foods. Chemical Pub. Co., New York, N.Y.

Postnote. (2006). Parliamentary Office of Science and Technology, number 274. 7 Milbank, London, United Kingdom.

Schönfeldt, H.C., Van Heerden, S.M., Van Niekerk, J.M. \& Visser, R.E. (1998). The nutrient content of South African chicken, raw and prepared according to either a dry or moist heat cooking method. ARC-ANPI, Private Bag X2, Irene, 0062, p22. ISBN 0-620-22150-X.

Schönfeldt, H.C., Van Niekerk, J.M., Visser, R.E. \& Heinze, P.H. (1997). Carcass and cut composition of South African beef. ARC-ANPI, Private Bag X2, Irene, 0062, p23. ISBN 0-620-21526-7.

Smit, L.E. \& Schönfeldt, H.C. (2006). The Nutritional Content of South African Milk and Milk Products. Part 1: milk powder, whey powder, condensed milk, fresh cream, butter (salted) and butter (unsalted). ARC-ANPI, Private Bag X2, Irene, 0062, p22. ISBN 1-866849-260-5.

Smit, L.E. \& Schönfeldt, H.C. (2006). The Nutritional Content of South African Milk and Milk Products. Part 2: goat milk, evaporated milk (light), evaporated milk (full), UHT milk (low fat), UHT milk (fat free) and drinking yoghurt. ARC-ANPI, Private Bag X2, Irene, 0062, p22. ISBN 1-866849-261-3. 
Smit, L.E., Smith, N., Schönfeldt, H.C. \& Heinze, P.H. (1998). The Nutritional content of South African milk and liquid milk products. ARC-ANPI, Private Bag X2, Irene, 0062, p22. ISBN 0-620-22150-X.

Smit, L.E., Smith, N., Schönfeldt, H.C. \& Heinze, P.H., (1998). The Nutritional content of South African cheeses. ARC-ANPI, Private Bag X2, Irene, 0062, p19. ISBN 0-620-22151-8.

Stadlmayr, B., Charrondiere, U.R., Addy, P., Samb, B., Enujiugha, V.N., Bayili, R.G., Fagbohoun, E.G., Smith, I.F., Thiam, I.\& Burlingame B. (2010). Composition of Selected Foods from West Africa. FAO. Rome, Italy. Available online at www.fao.org/infoods. Accessed 21 October 2011.

Standard Bank Centre for Agribusiness Leadership and Mentorship Development. 2011. Department of Agricultural Economics in the Faculty of AgriSciences. University of Stellenbosch. Stellenbosch, South Africa. Available online at http://thehopeproject.co.za. Accessed 24 October 2011.

Sunray. (2011). Sustainable Nutrition Research for Africa in the years to come. EU FP7 AFRICA. Available online at www.sunray.co.za. Accessed 19 October 2011.

Sustainable Developments. (2004). A Summary Report from the Conference on Assuring Food and Nutrition Security in Africa by 2020. International Institute for Sustainable Development, 28(6), 1-11. http://www.iisd.ca/download/pdf/sd/sdvol58num6e.pdf

Thompson Reuters. (2011). Web of Science. Availale online at http://thomsonreuters.com. Accessed 24 October 2011.

Van Heerden, S.M \& Schonfeldt, H.C. (XXX). Food comp activites

Whitehouse. (2009). Fact sheet: Presidential Memorandum on Scientific Integrity. Available online at http://www.whitehouse.gov/the-press-office/fact-sheet-presidential-memorandum-scientific-integrity. Accessed 19 October 2011.

Wolmarans P, Danster N, Dalton A, Rossouw K, Schönfeldt H. (2010). Condensed Food Composition Tables for South Africa. Medical Research Council, Cape Town, South Africa. ISBN: 1-919809-63-5. 
Food composition tables for international use (1949), Food composition table for use in Africa (1968), Food composition table for use in East Asia (1972), Table de composition des aliments \& l'usage (1976) and Food composition tables for the near east (1982).

World Population Prospects., The 2010 edition. 2011. United Nations Department of Economic and Social Affairs. http://esa.un.org/unpd/wpp/Excel-Data/population.htm

United Nations. 2010. The Millenium Development Goals Report 2010. New York, 2010. 
Table 1: AFROFOODS sub-regional division since 2000

\begin{tabular}{|l|l|}
\hline Sub-region & Countries \\
\hline ECSAFOODS & $\begin{array}{l}\text { Botswana, Djibouti, Eritrea, Ethiopia, Kenya, Lesotho, Madagascar, Malawi, } \\
\text { Mauritius, Namibia, Somalia, South Africa, Sudan, Swaziland, Tanzania, Uganda, } \\
\text { Zambia, Zimbabwe }\end{array}$ \\
\hline WAFOODS & $\begin{array}{l}\text { Mali, Senegal, Cote d'Ivoire, Niger, Burkina Faso, Sierra Leone, Liberia, Ghana, } \\
\text { Togo, Nigeria, Benin, Gambia }\end{array}$ \\
\hline CAFOODS & $\begin{array}{l}\text { Angola, Rwanda, Burundi, Congo Brazzaville, Democratic Republic of Congo, } \\
\text { Cameroon, Gabon, Central African Republic, Chad, Mozambique, Seychelles }\end{array}$ \\
\hline NAFOODS & Algeria, Morocco, Tunisia, Libya, Mauritania \\
\hline
\end{tabular}


Table 2: Plan of action for food composition at different levels

\begin{tabular}{|c|c|}
\hline Level & Activities \\
\hline $\begin{array}{l}\text { National level } \\
\text { (country) }\end{array}$ & $\begin{array}{l}\text { - } \text { Establishing a national network } \\
\text { - } \text { - Sentional coordination of existing data } \\
\text { - } \quad \text { Generation and compilation of data } \\
\text { - Validation of existing data } \\
\text { - } \quad \text { Communication } \\
\text { - Human resources training needs }\end{array}$ \\
\hline $\begin{array}{l}\text { Sub-regional level } \\
\text { (ECSAFOODS, } \\
\text { WAFOODS, } \\
\text { CAFOODS, } \\
\text { NAFOODS) }\end{array}$ & $\begin{array}{l}\text { - } \text { Establish new regional groupings } \\
\text { - Establish new sub-regional data centres } \\
\text { - Establish steering committees in each sub-region } \\
\text { - Establish working groups } \\
\text { - } \\
\text { Regular meetings for sub-regional centres }\end{array}$ \\
\hline $\begin{array}{l}\text { International level } \\
\text { (AFROFOODS) }\end{array}$ & $\begin{array}{l}\text { - Establish linkages with INFOODS } \\
\text { - Encourage publication of findings of working groups in Journal of Food } \\
\text { Composition and Analysis } \\
\text { - Encourage and support attendance in international training courses by } \\
\text { national and sub-regional members }\end{array}$ \\
\hline
\end{tabular}


Table 3: Working groups within AFROFOODS

\begin{tabular}{|c|c|c|c|}
\hline Working group & Functions & Chair & Member countries \\
\hline Working group on training & $\begin{array}{l}\text { - Identify training needs and institutions for training } \\
\text { - } \\
\text { - } \\
\text { - }\end{array}$ & Zimbabwe & $\begin{array}{l}\text { Ethiopia, Ghana, Nigeria, Senegal, South Africa, } \\
\text { Tunisia }\end{array}$ \\
\hline $\begin{array}{l}\text { Working group on analytical } \\
\text { procedures }\end{array}$ & $\begin{array}{l}\text { - Make recommendations for standardized methods } \\
\text { - Promote, identify and establish comparability of results } \\
\text { - } \text { Arrange participation in regional and international exchange of } \\
\text { - certified reference materials and standard local food samples } \\
\text { - Cooperate in seeking funding for these purposes }\end{array}$ & Kenya & $\begin{array}{l}\text { Benin, Cameroon, Ethiopia, Ghana, } \\
\text { Madagascar, Senegal, South Africa, Tanzania, } \\
\text { Zambia }\end{array}$ \\
\hline $\begin{array}{l}\text { Working group on communication } \\
\text { and dissemination }\end{array}$ & 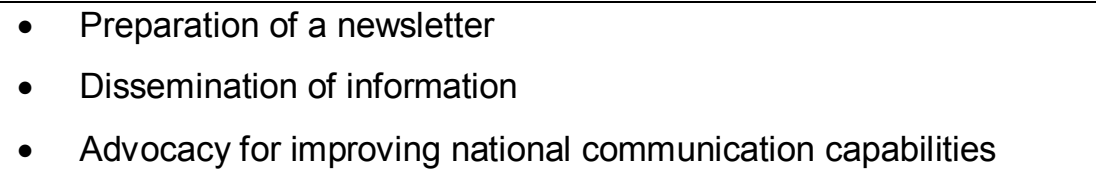 & Nigeria & $\begin{array}{l}\text { Cameroon, Ethiopia, Senegal, South Africa, } \\
\text { Tunisia, Zimbabwe }\end{array}$ \\
\hline $\begin{array}{l}\text { Working group on the use of food } \\
\text { composition databases }\end{array}$ & $\begin{array}{l}\text { - Increase awareness of the uses of food composition data } \\
\text { - Facilitate understanding of the uses of sub regional and national } \\
\text { - } \text { food composition data bases } \\
\text { - Promote of innovative uses of food composition data } \\
\text { - Pustainability of national food databases }\end{array}$ & Ghana & $\begin{array}{l}\text { Benin, Kenya, Lesotho, Madagascar, Mali, South } \\
\text { Africa, Tanzania, Uganda, Zambia }\end{array}$ \\
\hline $\begin{array}{l}\text { Working group on food legislation, } \\
\text { standards and regulations }\end{array}$ & $\begin{array}{l}\text { Encourage national standards, regulations and specifications that } \\
\text { will safeguard and improve the quality of the food supply } \\
\text { - Secure legal backing through appropriate legislation } \\
\text { - Encourage the adoption of standardized nutritional labelling of } \\
\text { foods }\end{array}$ & Uganda & $\begin{array}{l}\text { Benin, Ethiopia, Ghana, Kenya, Mali, Morocco, } \\
\text { Tanzania, Zambia, Zimbabwe }\end{array}$ \\
\hline Working group on data compilation & $\begin{array}{l}\text { - Providing advice relating to recommendations and resolutions of } \\
\text { expert committees } \\
\text { - Standardization of source codes and analytical codes specific to } \\
\text { the region } \\
\text { - Establish system linkages and interchange of data among } \\
\text { INFOODS regions }\end{array}$ & $\begin{array}{l}\text { South } \\
\text { Africa }\end{array}$ & $\begin{array}{l}\text { Cameroon, Ethiopia, Gambia, Kenya, } \\
\text { Madagascar, Mali, Nigeria, Senegal }\end{array}$ \\
\hline
\end{tabular}


Table 4: Food composition databases in Africa (Adopted from the INFOODS website 2012, www.fao.org/infoods)

\begin{tabular}{|c|c|}
\hline Africa & $\begin{array}{l}\text { - Répertoire général des aliments 3: Table de composition des fruits exotiques, fruits } \\
\text { de cueillette d'Afrique, } 1993 \\
\text { - Carte des Calories et des Vitamines pour } 150 \text { Aliments Africains, undated } \\
\text { - } \quad \text { Food Composition Table for Use in Africa, } 1968\end{array}$ \\
\hline East Africa & $\begin{array}{l}\text { - The Composition of Foods Commonly Eaten in East Africa, } 1988 \\
\text { - Food Composition Table for Energy and Eight Important Nutrients in Foods } \\
\text { Commonly Eaten in East Africa } 1987\end{array}$ \\
\hline West Africa & $\begin{array}{l}\text { - West African Food Composition Table / Table de composition des aliments } \\
\text { d'Afrique de l'Ouest, } 2012 \\
\text { - Composition of Selected Foods from West Africa, } 2010 \\
\text { - Aliments de l'Ouest Africain--Tables de Composition, } 1965 \\
\text { - Plantes alimentaires de l'Ouest africain--Etude botanique, chimique et biologique } \\
\text { des végétaux alimentaires, } 1965\end{array}$ \\
\hline Cameroon & $\begin{array}{ll}\text { - } & \text { Les Aliments d'Origine Végétale au Cameroun, } 1966 \\
\text { - } & \text { Table Provisoire de Composition des Aliments du Sud-Cameroun, } 1957\end{array}$ \\
\hline Congo & $\begin{array}{l}\text { - Tables de composition alimentaire pour la République Démocratique du Congo, } \\
1966\end{array}$ \\
\hline Egypt & - $\quad$ Food Composition Tables, 1985 \\
\hline Ethiopia & $\begin{array}{l}\text { - Food Composition Table for Use in Ethiopia IV, } 1998 \\
\text { - Expanded Food Composition Table for Use in Ethiopia, undated } \\
\text { - Food Composition Table for Use in Ethiopia II: Amino Acid Content and Biological } \\
\text { Data on Proteins in Ethiopian Foods, } 1975 \\
\text { - Food Composition Table for Use in Ethiopia, } 1968\end{array}$ \\
\hline Gambia & $\begin{array}{l}\text { - Food Composition Table for use in The Gambia, } 2011 \\
\text { - Foods of Rural Gambia, } 1996 \\
\text { - Gambian Foods: GAFNA Handbook. Energy and Protein Tables, } 1987 \\
\text { - Foods of Rural Gambia, } 1979\end{array}$ \\
\hline Ghana & $\begin{array}{l}\text { - Nutrient composition of } 167 \text { food items from Ghana, The Philippines, Italy and } \\
\text { Finland, } 1983 \\
\text { - Composition of Foods Commonly Used in Ghana, } 1975\end{array}$ \\
\hline Kenya & $\begin{array}{l}\text { - National Food Composition Tables and The Planning of Satisfactory Diets in Kenya, } \\
1993 \\
\text { - Chemical Composition of Some Kenya Foodstuffs, } 1951\end{array}$ \\
\hline Lesotho & - Lesotho food composition tables, DATE \\
\hline Mali & $\begin{array}{l}\text { - } \quad \text { Table de composition d'aliments du Mali / Food Composition Table for Mali, } 2004 \\
\text { - } \quad \text { Table de composition d'aliments du Mali, } 1998 \text { (French) } \\
\text { - } \quad \text { The Composition of Malian Foods, } 1995 \text { Draft }\end{array}$ \\
\hline Mozambique & 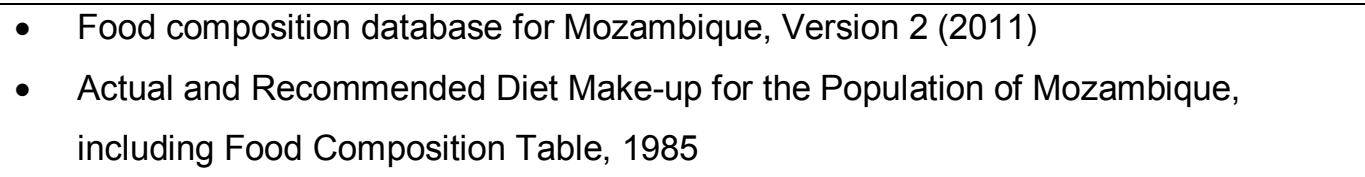 \\
\hline
\end{tabular}




\begin{tabular}{|c|c|}
\hline Nigeria & $\begin{array}{l}\text { - } \quad \text { Nutrient Composition of Commonly Eaten Foods in Nigeria - Raw, Processed and } \\
\text { Prepared, } 1995 \\
\text { - Nigerian Foods and Feedingstuffs, } 1968 \text { (English) }\end{array}$ \\
\hline Senegal & $\begin{array}{l}\text { - Chemical Composition of } 66 \text { Samples of Leaves, Fruits, Seeds and Tubercles } \\
\text { Eaten in Senegal, } 1961\end{array}$ \\
\hline South Africa & 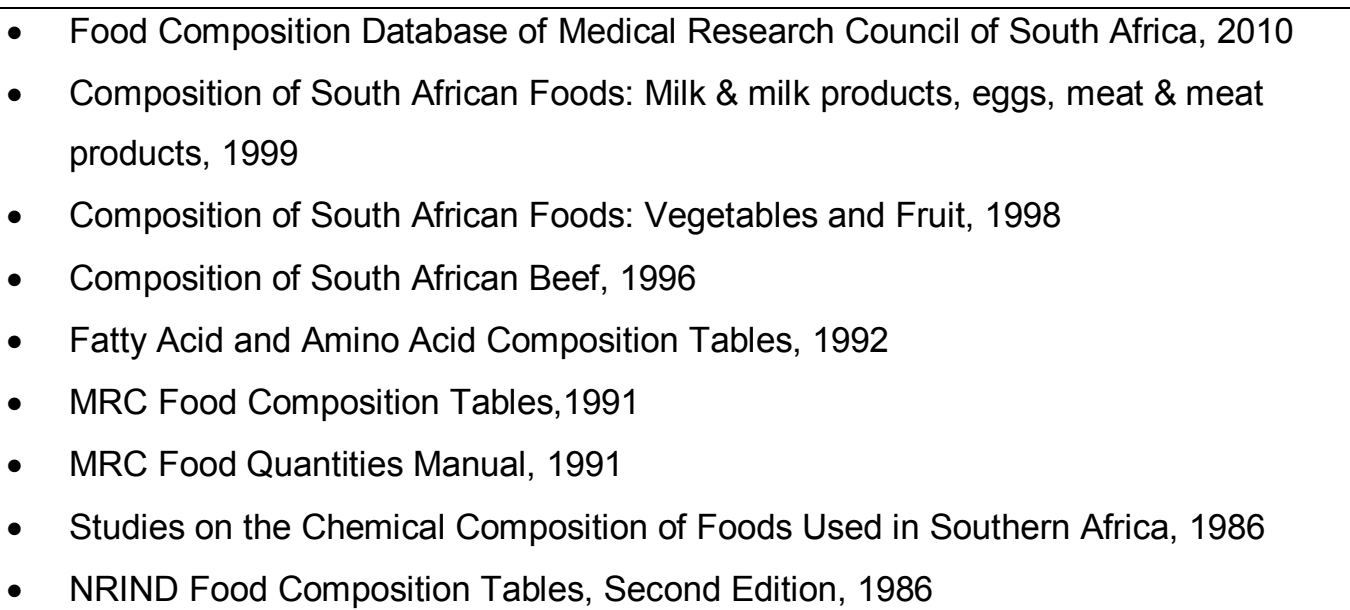 \\
\hline Sudan & Sudan Food Composition Tables, 1986 \\
\hline Tanzania & $\begin{array}{l}\text { - Tanzania Food Composition Tables, } 2008 \\
\text { - The Composition of Foods Commonly Eaten in East Africa, } 1988 \text { (English) } \\
\text { - Food Composition Table for Use in a Research Program on Vitamin A Deficiency in } \\
\text { - Tanzania, } 1985 \\
\text { - The Tanzania Food Tables, } 1974\end{array}$ \\
\hline Togo & - Table de Composition des Aliments du Togo, 1957 \\
\hline Tunisia & Enquêtes Alimentaires en Tunisie, 1952 \\
\hline Uganda & A Food Composition Table for Central and Eastern Uganda, 2012 \\
\hline Zambia & Tables of the Values of Zambian Foodstuffs, 1971 \\
\hline Zimbabwe & Nutritive Value of Foods of Zimbabwe, 1989 \\
\hline
\end{tabular}


Table 5: Food composition training courses presented in Africa from 2001 to 2010

\begin{tabular}{|c|c|c|c|}
\hline $\begin{array}{l}\text { Food composition courses } \\
\text { held in Africa }\end{array}$ & Year & $\begin{array}{l}\text { Number of } \\
\text { African } \\
\text { participants }\end{array}$ & Participating countries \\
\hline 1st ECSAFOODS course & 1997 & 23 & $\begin{array}{l}\text { Benin, Botswana, Ethiopia, Ghana, Kenya, Malawi, } \\
\text { Mozambique, Namibia, South Africa, Swaziland, Tanzania, } \\
\text { Uganda, Zambia, Zimbabwe }\end{array}$ \\
\hline 2nd ECSAFOODS course & 1999 & 22 & $\begin{array}{l}\text { Ghana, Kenya, Lesotho, Malawi, Mali, Namibia, South Africa, } \\
\text { Swaziland, Tanzania, Zimbabwe }\end{array}$ \\
\hline 3rd ECSAFOODS course & 2002 & 23 & $\begin{array}{l}\text { Benin, Burkina Faso, Ethiopia, Ghana, Kenya, Malawi, Nigeria, } \\
\text { South Africa, Swaziland, Tanzania, Uganda }\end{array}$ \\
\hline 4th ECSAFOODS course & 2005 & 21 & $\begin{array}{l}\text { Cameroon, Kenya, Lesotho, Malawi, Nigeria, South Africa, } \\
\text { Tanzania }\end{array}$ \\
\hline $\begin{array}{l}\text { 1st Francophone West and } \\
\text { Central African Workshop }\end{array}$ & 2009 & 14 & Cameroon, Gambia, Ghana, Nigeria, Sierra Leone, Zambia \\
\hline $\begin{array}{l}\text { 1st Anglophone West and } \\
\text { Central African Workshop }\end{array}$ & 2009 & 14 & $\begin{array}{l}\text { Benin, Burkina Faso, Cameroon, Cote d'Ivoire, Niger, Chad, } \\
\text { Togo }\end{array}$ \\
\hline $1^{\text {st }}$ International course & 2010 & 17 & $\begin{array}{l}\text { Botswana, Cameroon, Ethiopia, Kenya, Mozambique, Nigeria, } \\
\text { South Africa, Tanzania, Uganda, Zimbabwe }\end{array}$ \\
\hline \multicolumn{4}{|c|}{ Other international courses with African participants } \\
\hline Wageningen course, Belgium & 1992 & 1 & Zimbabwe \\
\hline Wageningen course, Belgium & 1994 & 6 & Egypt, Ethiopia, Ghana, Tunisia \\
\hline Wageningen course, Belgium & 1996 & 6 & Burkino Faso, Egypt, Zambia, Zimbabwe \\
\hline Wageningen course, Belgium & 1998 & 2 & Egypt, Zimbabwe \\
\hline Wageningen course, Belgium & 2001 & 1 & Malawi \\
\hline Wageningen course, Belgium & 2003 & 3 & Benin, Kenya, Morocco \\
\hline Wageningen course, Belgium & 2005 & 3 & Burkina Faso, Kenya, Morocco \\
\hline EuroFIR course, Bratislava & 2006 & 1 & Algeria \\
\hline Wageningen course, Belgium & 2007 & 5 & Benin, Cameroon, Kenya, Mali \\
\hline EuroFIR course, Bratislava & 2008 & 1 & Egypt \\
\hline $\begin{array}{l}\text { OCEANIAFOODS course, } \\
\text { Australia }\end{array}$ & 2009 & 1 & Zimbabwe \\
\hline Wageningen course, Belgium & 2009 & 4 & Ghana, Malawi, Tanzania, Uganda \\
\hline $\begin{array}{c}2^{\text {nd }} \text { Asian Graduate Course, } \\
\text { India }\end{array}$ & 2006 & 4 & Botswana, Cameroon, Nigeria \\
\hline Near East Course, Iran & 2008 & 3 & Egypt, Libya, Tunisia \\
\hline
\end{tabular}


Table 6: List of keywords used to conduct search of scientific articles on Food Composition from Africa

\begin{tabular}{|l|l|l|l|}
\hline Database & $\begin{array}{l}\text { Date } \\
\text { accessed }\end{array}$ & Search Strategy (Keywords) & $\begin{array}{l}\text { Number } \\
\text { of hits }\end{array}$ \\
\hline $\begin{array}{l}\text { Web of Science } \\
\text { (Web of } \\
\text { Knowledge) }\end{array}$ & $10 / 05 / 2012$ & $\begin{array}{l}\text { CU=(Algeria OR Angola OR Benin OR Botswan OR "Burkina Faso" OR Burkinabe OR Burund OR Cameroon OR } \\
\text { "Cape Verde" OR "Cape Verdean" OR "Central African Republic" OR Chad OR Comoros OR Comorian OR } \\
\text { "Democratic Republic of Congo" OR "Republic of Congo" OR Congo OR Congolese OR "Cote d'Ivoire" OR } \\
\text { "Republic of Cote d'Ivoire" OR "Ivory Coast" OR Ivorian OR Djibouti OR Egypt OR "Arab Republic of Egypt" OR } \\
\text { "Equatorial Guinea" OR Guinean OR Eritrea OR Ethiopia OR Gabon OR Gambia OR Ghana OR Guinea OR } \\
\text { "Guinea-Bissau" OR Kenya OR Kenyan OR Lesotho OR Liberia OR Libya OR Madagasca OR Malawi OR Mali } \\
\text { OR Malian OR Mauritania OR Mauritius OR Mauritian OR Morocc OR Mozambique OR Mozambican OR } \\
\text { Namibia OR Niger OR Nigeria OR Rwanda OR "Sahara Occidental" OR "Sao Tome and Principe" OR Sao } \\
2012 \\
\text { Tomean OR Senegal OR Seychell OR "Sierra Leone" OR "Sierra Leonian" OR Somali OR "South Africa" OR } \\
\text { 2012 } \\
\text { "South African" OR Sudan OR Swaziland OR Swazi OR Tanzania OR Togo OR Tunisia OR Uganda OR } \\
\text { "Western Sahara" OR Zambia OR Zimbabwe OR Africa) AND TS=("nutrient content" OR "food composition" OR } \\
\text { "vitamin content" OR "protein content" OR "mineral content" OR "nutrient composition") AND Document } \\
\text { Types=(Article) }\end{array}$ \\
\hline
\end{tabular}

